\title{
分オーダーの給湯負荷データを用いた 住宅用マイクロコジェネの運転方法・蓄熱容量の検討
}

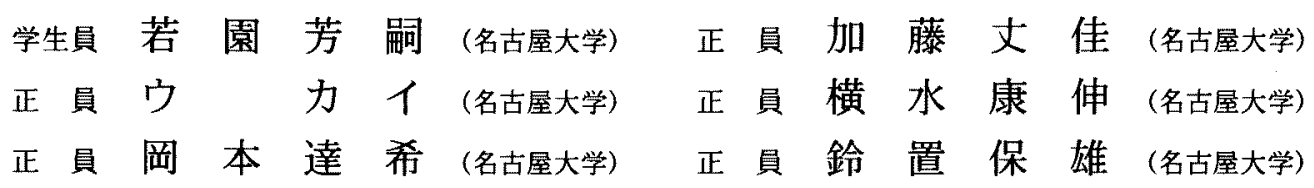

A Study on Operational Pattern and Heat-storage Capacity of Micro Co-generation System for House Use Based on Minute-order Hot Water Load

Yoshitsugu Wakazono, Student Member, Takeyoshi Kato, Member, Kai Wu, Member, Yasunobu Yokomizu, Member, Tatsuki Okamoto, Member, Yasuo Suzuoki, Member (Nagoya University)

In recent years, introduction of micro co-generation system ( $\mu \mathrm{CGS}$ ) is expected to be a promising measure for improving energy efficiency in house. This paper discusses an operation pattern and heat-storage capacity of $\mu$ CGS introduced in house use by using hot water load pattern expressed in minute. The simulation results reveal that (i)the introduction of $\mu \mathrm{CGS}$ drastically contributes to energy saving, (ii)the required heat-storage capacity turned out to be in feasible volume range, (iii)the calculation based on hourly averaged hot water load patterns underestimates the heat-storage capacity, (iv) when reverse power flow is not accepted, value of $\mu \mathrm{CGS}$ as a hot water supply is diminished because operation of $\mu \mathrm{CGS}$ is considerably restricted and $\mu \mathrm{CGS}$ cannot supply sufficient hot water.

キーワード: 省エネルギー、マイクロコージエネレーション、蓄熱槽、蓄熱容量、給湯負荷

\section{1. はじめに}

近年、数 $\mathrm{kW}$ クラスの超小型コージェネレーションシス テム(CGS)、いわゆるマイクロコジェネが開発・発売され つつある。特に、固体高分子型然料電池 (PEFC) やガスエ ンジン $(\mathrm{GE})$ による戸建住宅向けの数 $\mathrm{kW}$ クラスのマイク ロコジェネの開発が注目されている(1)(2)。今後の高効率化、 低コスト化によってマイクロコジェネが各家庭に広く浸透 すれば、民生部門における省エネルギー化を促進できる可 能性がある。

従来の数十 $\mathrm{kW}$ クラス以上の CGS の場合、複数の需要 家に対して電力および熱供給を行うため、CGSからみた負 荷は時間的に平均化されると考えられる。これに対し、戸 建住宅のように非常に小規模な需要家では、負荷の発生源 が限られているため、負荷の発生時間や発生量が変動しゃ すいと考えられる。特に、給湯負荷は大規模な負荷が離散 的に発生する。見在、一般的に用いられているガス給湯器 やボイラの場合には、このような急激な給湯負荷の変動に 対して比較的よく対応できる。しかし、ガスエンジン等を 原動機とするマイクロコジェネの場合、機器の特性から、 このような急激に発生する給湯負荷に応じた熱供給は困難 であり、蓄熱槽の設置が必要である。ただし、住宅の場合、
機器の設置スペースが限定されているため、システム全体 の容積がマイクロコジェネ導入に大きく影響すると考えら れる。このため、システムを設計する場合には、負荷の分 オーダーでの発生パターンを十分考虑し、適切なマイクロ コジェネ設備容量や蓄熱容量を決定する必要がある。そこ で、本論文では、戸建住宅を対象に、分単位で記述された 給湯負荷データを用いて、マイクロコジェネを導入する場 合の運転方法・蓄熱容量に関する検討を試みた。

\section{2. 評価モデル}

\section{$\langle 2 \cdot 1\rangle$ システムの構成}

マイクロコジェネ導入評価モデルとして、延床面積 $133 \mathrm{~m}^{2}$ の戸建住宅を想定した。評価モデル内でのエネルギー供給 の概念図を図 1に示す。マイクロコジェネのシステムを構 築する場合、ガス給湯器等の補助熱源を併せて設置するこ とも考えられる。しかし、設備の二重投資となり、従来の ガス給湯器と比較して、普及に不利となる。また、マイク ロコジェネに補助熱源を併設することは、設置スペースが 限られる住宅においては好ましくない。そこで、本モデル では、マイクロコジェネを従来の給湯器の代替と位置づけ、 補助熱源は設置されないものとした。したがって、給湯負 荷はマイクロコジェネからの回収熱のみで賄われる。ただ 
し、蓄熱槽の導入を想定し、マイクロコジェネが運転され ていない時間帯にも温水の供給ができるものとした。冷房 負荷および暖房負荷は電力負荷として取り扱い、マイクロ コジェネからの供給電力と系統からの買電力とによって賄 われると想定した。なお、㕌房で消費されるエネルギー(3) は、全て都市ガスで供給されると想定し、マイクロコジエ ネからの直接的なエネルギー供給は行われないものとした。

マイクロコジェネとしては、現在の機器開発状況を考慮 して、ガスエンジン型 (発電効率 $22.5 \%$ 、熱回収効率 45 \%)、然料電池型 (発電勃率 $35 \%$ 、熱回収効率 $40 \%$ ) の 2 種類を想定した (1) (2)。省エネルギ一性や機器の部分負荷特 性から、ガスエンジンの最低出力を定格出力の $40 \%$ 、燃 料電池の最低出力を定格出力の $33 \%$ と設定した (2)。また、 蓄熱槽では、マイクロコジェネからの回収熱が $80^{\circ} \mathrm{C}$ の温水 として蓄熱されると想定し、名古屋市における月別の市水 温度 ${ }^{(4)}$ を考慮して蓄熱量を算定した。さらに、マイクロコ

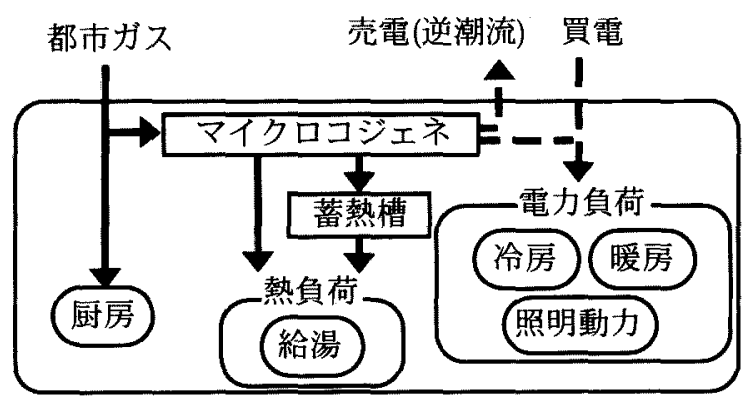

図 1 評価モデル

Fig. 1. Simulation model.

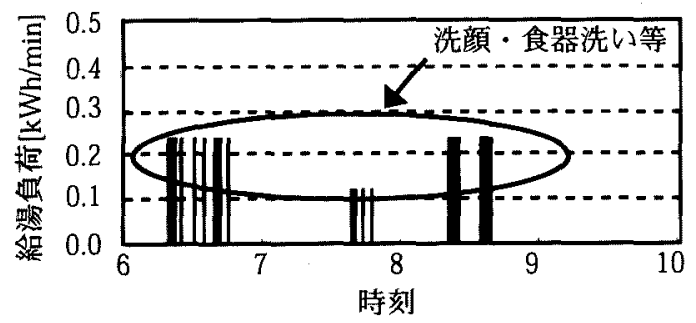

(a) 6 時 $~ 10$ 時

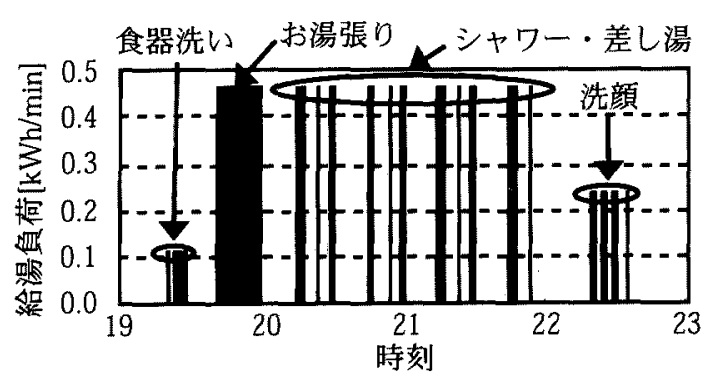

(b) 19 時 23 時

図 21 日の給湯負荷の時間変化 (冬期)

Fig. 2. Hot water load pattern.
ジェネからの余剩電力については、系統へ逆潮流できる場 合とできない場合を想定した。

省エネルギ一性の比較ケースとして、冷房負荷、暖房負 荷および照明動力負荷を系統からの買電力 (発電効率 : 40 \%、所内率: $4 \%$ 、送電口ス: $5 \%$ )、給湯負荷をガス給湯 器 (效率 : $80 \%$ ) で賄う場合を想定した。比較ケースにお ける年間一次エネルギー消費量は $30.2 \mathrm{Gcal}$ であった。

\section{$\langle 2 \cdot 2\rangle$ 給湯負荷および電力負荷}

戸建住宅での給湯負荷として、集合住宅を対象とした場 合に用いられる時間オーダーの給湯負荷データを用いると、 離散的な負荷の時間変化が蓄熱容量の算定に及ぼす影響を 考虑できない。そこで、本論文では、給晹負荷として、分 単位の時間変化を想定した ${ }^{(5)}$ 。文献 (5) で区分されている 5 つの季節帯 (冬期、中間期 A、中間期 B、中間期 C、夏 期) のうち、冬期の 1 日の給湯負荷の時間変化を図 2 に示 す。給湯の主な用途は、台所での食器洗い、洗濯、浴槽へ の㧍湯張り、入浴時のシャワー・差し湯である。図 2(b)に 示すように、特に、19 時〜22 時に発生している浴室での お湯張りやシャワーにおいて、最も時間当たりの給湯量が 大きい。

冷暖房負荷および照明動为負荷については、24 時間帯X 12ヶ月の時間変化を想定した。1ヶ月当たりの給湯負荷、冷 房負荷、暖房負荷および照明動力負荷を図 3 に示す ${ }^{(3)}-\left({ }^{(6)}\right.$ 。 給湯負荷および冷暖房負荷は、季節帯によって大きく変化 する。一方、照明動力負荷は、季節帯によらずほぼ一定で ある。なお、冷暖房負荷は、電力によって賄われるものと し、冷房負荷を電力で賄う場合の COPを 3.0、暖房負荷を 電力で賄う場合の COP 3.5 として電力負荷に換算した。

\section{$\langle 2 \cdot 3\rangle$ 目的関数およひ評価方法}

モデル内のエネルギー需給を混合整数計画問題として定 式化した。モデルでは、月毎に 1 日のエネルギ一需給を定

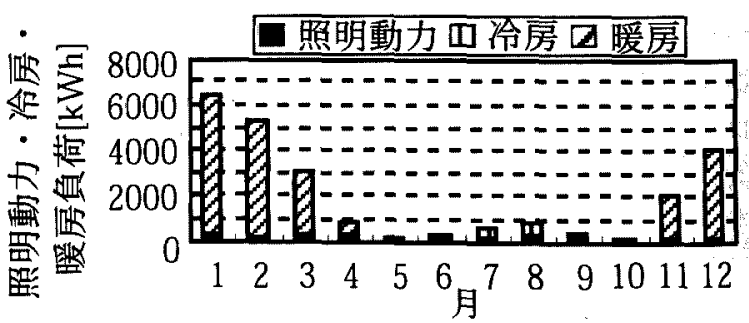

(a) 電力負荷

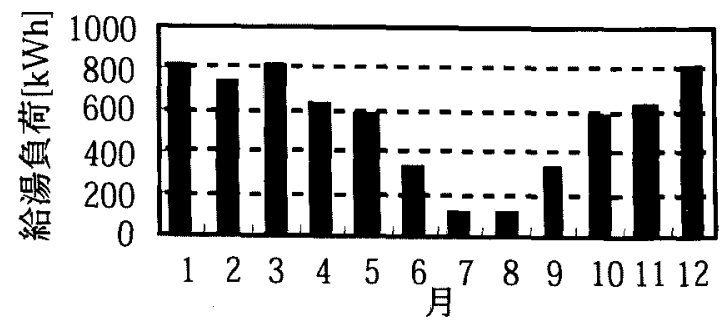

（b）熱負荷

図 3 1ヶ月当たりの熱負荷・電力負荷

Fig. 3. Monthly heat and electricity load. 
式化し、最適化評価を行っている。定式化に用いた変数、定 数、制秎条件および目的関数、評洒項目を以下に示す。な お、時刻を表す引数として $h(0 \sim 23)$ および $m(0 \sim 59)$ を用 い。

$$
\begin{aligned}
\frac{\text { 変数 }}{s(h, m):} & h \text { 時 } m \text { 分における蓄熱量 }[\mathrm{kcal}] \\
\delta(h): & h \text { 時におけるマイクロコジェネ運転状態を } \\
& \text { 示す } 0-1 \text { 変数 }(0: \text { 停止. } 1: \text { 運転 }) \\
E: & 1 \text { 日あたりの一次エネルギ一消費量 }[\mathrm{kcal}] \\
q_{\mathrm{cgs}}(h): & h \text { 時における } 1 \text { 分当たりの } \\
& \text { マイクロコジェネ供給熱量 }[\mathrm{kcal}] \\
e_{c g s}(h): & h \text { 時における } 1 \text { 時間当たりの } \\
& \text { マイクロコジェネ発電電力量 }[\mathrm{kWh}] \\
f(h): & h \text { 時における } 1 \text { 時間当たりのマイクロコジェ } \\
& \text { ネ投入エネルギー量を定格運転時の投入エ } \\
& \text { ネルギー量で規格化した䛧 }
\end{aligned}
$$

\section{定数}

$$
\begin{aligned}
q(h, m): & h \text { 時 } m \text { 分における給湯負荷 }[\mathrm{kcal}] \\
e(h): & h \text { 時における電力負荷 }[\mathrm{kWh}] \\
K_{c g s}: & \text { マイクロコジェネ設備容量 }[\mathrm{kW}] \\
\alpha: & \text { マイクロコジェネの定格時発電効率 }[\%] \\
\beta: & \text { マイクロコジェネの定格時熱回収効率 }[\%] \\
\gamma: & 1 \text { 分当たりの蓄熱効率 }[\%](87 \% / \text { day に相当 }) \\
\eta: & \text { 系統総合効率 }(=0.4 \times(1-0.04) \times(1-0.05))
\end{aligned}
$$

\section{目的関数}

モデル内では、1 日の一次エネルギ一消費量 $E$ を目的関 数とし、それが最小化されるようなマイクロコジエネ運転 パターンを算定した。ただし、ガスエンジンの起動時には、 金属の急激な熱膨張による機器の損傷を防ぐための暖管運 転が必要であり、燃料電池の起動時には、改質器を加熱す る必要がある。このため、マイクロコジェネは、ガス給湯 器のように起動してすぐに給湯できないため、マイクロコ ジェネを短時間で起動・停止することは現実的ではない。 また、1 分間あたりの給湯負荷はマイクロコジェネからの 1 分間あたりの熱供給量よりも大きく、マイクロコジェネ の排熱は一旦蓄熱槽に蓄えられてから供給されることにな る。このため、マイクロコジェネの運転時間を分オーダー で調整可能であると想定しても、システムの最適設計に及 ぼす影響は小さい。そこで、本論文ではマイクロコジェネ は、電力負荷の時間変化を考慮して、1時間単位で起動・停 止や出力調整が行われると想定した。

$$
\begin{aligned}
E= & \frac{100}{\alpha} \times K_{c g s} \times\left(\sum_{h} f(h)\right) \times 860 \\
& +\frac{\sum_{h}\left(e(h)-e_{c g s}(h)\right)}{\eta} \times 860 \rightarrow \min \cdots
\end{aligned}
$$

制約条件

\section{・蓄熱量に関する制約}

$h$ 時 $m$ 分の給湯負荷 $q(h, m)$ は、蓄熱槽に蓄えら れた熱と $h$ 時 $m$ 分のマイクロコジェネからの供給熱 $q_{c g s}(h) \times \delta(h)$ とによって賄われ、余った熱量が蓄熱 槽に蓄熱される。

$$
\begin{aligned}
s(h, m)= & q_{\mathrm{cgs}}(h) \times \delta(h) \\
& +\frac{\gamma}{100} \times s(h, m-1)-q(h, m) \cdots
\end{aligned}
$$

1 日の最後の給湯負荷を賄った時点で蓄熱槽に残つ た熱量は、廃童されず翌日の給湯負荷に利用される。 実際の運用でも、マイクロコジェネの運用を開始する 時点で前日の残りの熱量が蓄熱槽に存在する場合には、 マイクロコジェネの運転開始時刻を変更することによ り対応できる。また、モデルでは、蓄熱槽ができるだけ 小さくなるように、1日の最低蓄熱量を 0 に設定した。

\section{・マイクロコジェネ出力制約}

○ガスエンジン型

$$
0.40 \times K_{c g s} \times \delta(h) \leq e_{c g s}(h) \leq K_{c g s} \times \delta(h)
$$

然料電池型

$$
0.33 \times K_{c g s} \times \delta(h) \leq e_{c g s}(h) \leq K_{c g s} \times \delta(h)
$$

・マイクロコジェネ部分負荷特性 $(\delta(h)=1$ の場合) ○ガスエンジン型

$$
\begin{aligned}
q_{c g s}(h)= & \frac{1}{60} \times \frac{\beta}{\alpha} \times 860 \times K_{c g s} \\
& \times(1.063 \times f(h)-0.063) \cdots . \\
e_{c g s}(h)= & K_{c g s} \times(1.528 \times f(h)-0.528)
\end{aligned}
$$

\section{燃料電池型}

$$
\begin{aligned}
& q_{c g s}(h)=\frac{1}{60} \times \frac{\beta}{\alpha} \times 860 \times K_{c g s} \times f(h) . \\
& e_{c g s}(h)=K_{c g s} \times(1.063 \times f(h)-0.063)
\end{aligned}
$$

\section{評価項目}

・蓄熱容量

各月の $h$ 時 $m$ 分の蓄熱量 $s(h, m)$ と市水温度から、 $h$ 時 $m$ 分に蓄熱される温水量を月別に算定し、一年間 での最大值を蓄熱容量とした。

・一次エネルギー削減率

$$
\begin{aligned}
& \text { 一次エネルギー削減率 }[\%]=100 \times \\
& \left(1-\frac{\text { コジエネ導入後の年間一次エネルギー消費量 }}{\text { コジエネ導入前の年間一次エネルギー消費量 }}\right) \\
& \text { マイクロコジェネ導入後の年間一次エネルギー消費 }
\end{aligned}
$$

量は、最適化計算で得られた各月の1日あたりの一次 エネルギー消費量に各月の日数を乗じて 1 年間で合計 した值である。

・設備利用率

$$
\text { 設備利用率 }[\%]=100 \times \frac{\text { 年間発電電力量 }}{K_{c g s} \times 24 \times 365}
$$




\section{3. 逆潮流が可能な場合の最小蓄熱容量}

\section{〈3・1〉 マイクロコジェネの導入評価}

設備容量: $2.0 \mathrm{~kW}$ の場合の 12 月におけるマイクロコジェ ネ出力および蓄熱量の時間変化をそれぞれ図 4および図 5 に示す。図 4から、ガスエンジン型、然料電池型いずれの 場合も、マイクロコジェネは給湯負荷の発生する朝や夕方 から夜間の時間帯に集中的に運転されている。また、機器 の熱電比から、ガスエンジンよりも燃料電池の方が熱供給 能力が小さい。このため、1日の給湯負荷を賄うために必 要な稼働時間は、燃料電池の方が長くなる。

また、マイクロコジェネの1 分当たりの熱供給量は、実 際の給湯負荷の1分間あたりの熱量よりもはるかに小さい。 そのため、マイクロコジェネは給湯負荷の時間変化に追随 できず、マイクロコジェネのみで全ての熱觬荷を賄うため には、あらかじめ必要な熱量を蓄熱槽に蓄えておく必要が ある。特に、図 2(b) に示したように、19 時〜22 時の時間 帯は、住宅内では入浴が行われるため、浴槽への抢湯張り、 シャワーなどの給湯負荷が集中的に発生する。その結果、 図5のように、蓄熱量は給湯負荷の中で最も大規模な浴槽 へのお湯張りが行われる 20 時前に最大となり、その直後に 急激に減少している。さらに、然料電池型の方がカスエン ジン型よりも 1 分当たりの熱供給量が小さいため、最大蓄 熱量は、燃料電池型の方が大きくなる。したがって、戸建 住宅では、浴室での給湯負荷や機器の熱電比が蕃熱容量に 大きく影響するといえる。

マイクロコジェネの設備容量が $1.0 \sim 3.0 \mathrm{~kW}$ の各場合に おいて必要な蓄熱容量を図 6、年間設備利用率を図 7 に示

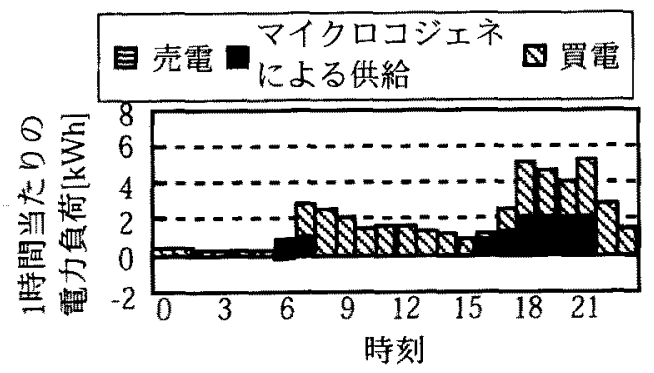

(a) ガスエンジン型 : $2.0 \mathrm{~kW}$

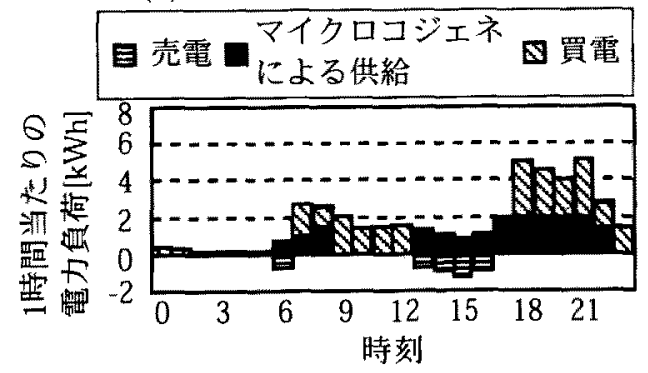

(b) 燃料電池型 : $2.0 \mathrm{~kW}$

図 4 12 月のマイクロコジェネ運転パターン

Fig. 4. Operational pattern of $\mu$ CGS in December.
す。設備容量が小さい場合には、マイクロコジェネの時間 当たりの熱供給量が少なく、マイクロコジエネを長眭間運 転し、必要な熱量を前もつて蓄熱させておく必要がある。 そのため、マイクロコジェネの設備容量が大きくなるにつ れて、蓄熱容量は小さくなり、設備容量が $3.0 \mathrm{~kW} の$ 場合の 蓄熱容量は、ガスエンジン型で 97 リトル、燃料電池型 で148リットルである。熱電比の関係から、ガスエンジン 型の方が然料電池型よりも蓄熱容量が小さくなつているが、 設備利用率は低くなる。ただし、図7に示すように、マイ クロコジェネの設備容量が $3.0 \mathrm{~kW}$ になると、年間の設備利 用率は、カスエンジン型で $10 \%$ 、燃料電池型で $20 \%$ にま で低下する。なお、現在実用化されている媣夜電力を利用 した户建住宅向けの電気温水器の容量は的 400 リットルで ある。このため、実現可能な熱容量の範同内で、戸建住 宅にマイクロコジェネを導入できるといえる。なお、然料 舟池の設備容量が $1.0 \mathrm{~kW}$ の場合、マイクロコジェネの熱 供給能力が小さいため、給湯負荷が多い1〜3月および 12 月にはマイクロコジェネ単独で 1 日の熱負荷が賄えないた め、解は存在しなかった。

マイクロコジェネの各設備容量における一次エネルギー 削減率を図 8に示す。同図のように、ガスエシジン型、然料 電池型のいずれの場合も、マイクロコジェネの導入によっ て一次エネルギー消費量は $3 \sim 21 \%$ 削隇される。カスエン ジン型と燃料電池型とを比較した場合、総合効率が高い燃 料電池型の方がガスエンジン型よりも高い省エネルギー性 を実現できる。なお、今後新技術の導入により、系統電力 の発電効率が向上することが予想される。例えば、系統の 発電効率が $50 \%$ となると、一次エネルギ一削減率は図 8 よ

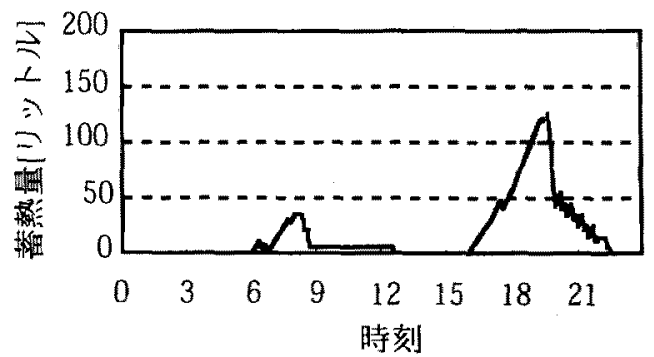

(a) ガスエンジン型 : $2.0 \mathrm{~kW}$

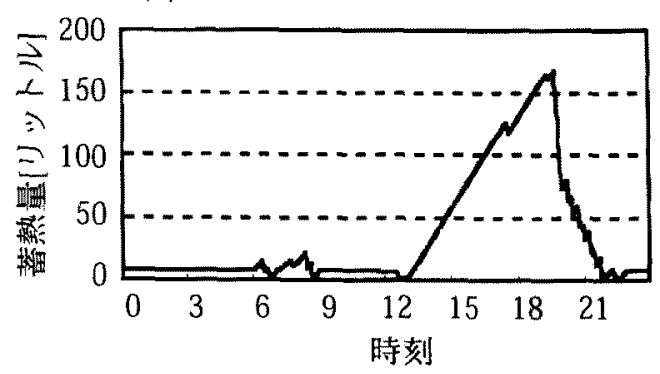

(b) 燃料電池型 : $2.0 \mathrm{~kW}$

図 512 月の蓄熱量の時間変化

Fig. 5. Daily heat storage pattern in December. 


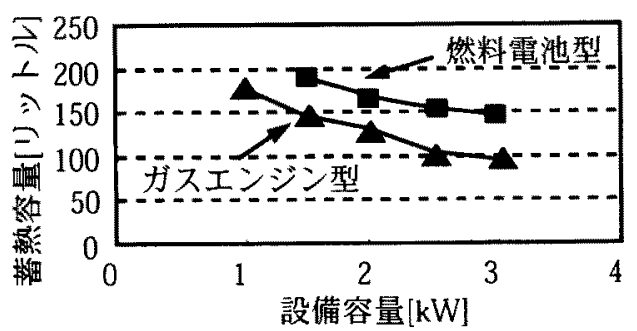

図6 マイクロコジェネの設備容量に対する蓄熱 容量の推移

Fig. 6. Heat-storage capacity as a function of capacity of $\mu$ CGS.

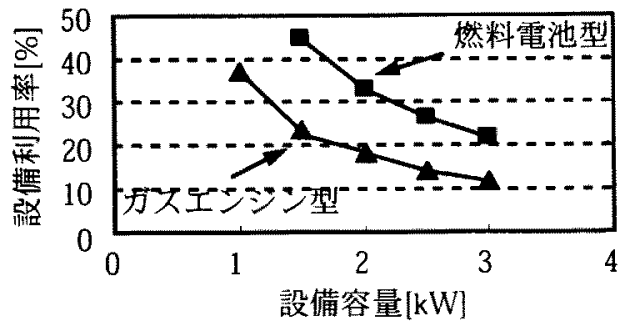

図 7 マイクロコジェネの設備容量に対する設備 利用率の推移

Fig. 7. Capacity factor of $\mu$-CGS as a function of capacity of $\mu$ CGS.

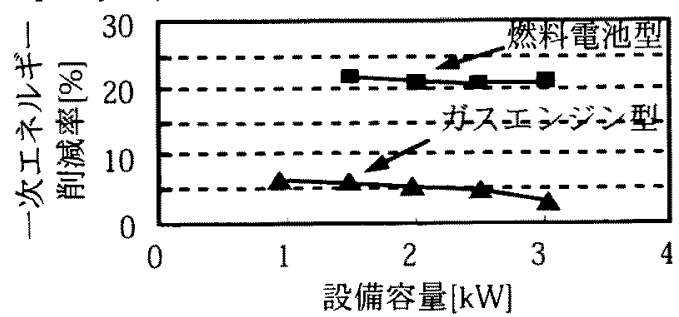

図 8 マイクロコジェネの設備容量に対する一次 エネルギー削隇率の推移

Fig. 8. Reduction rate of primary energy consumption as a function of capacity of $\mu$ CGS.

りも約 5〜7ポイント低下することを別途確認している。た だし、系統内の発電機の数が多いので、高効率発電機への 置き換えが進み、系統全体の発電効率が $50 \%$ \%たで向上 するには、まだ多くの時間がかかる。したがって、本論文 では系統の発電効率を $40 \%$ として検討した。

\section{〈3-2〉給湯負荷を 1 時間の平均值とした場合の検討}

本節では、戸建住宅へのマイクロコジェネ導入評価に対 して、集合住宅を対象とした場合に使用されているような 1 時間オーダーで記述された給湯負荷パターンを利用した 場合について検討する。そこで、給晹負荷として、分オ一 ダーの給湯負荷データを 1 時間当たりで平均化した数値を 使用し、前節と同様の計算機モデルによってマイクロコジェ ネの最適形態を検討した。

設備容量を変化させた場合の蓄熱容量の推移を図 9 に示 す。同図からわかるように、設桶容量が大きくなるにした

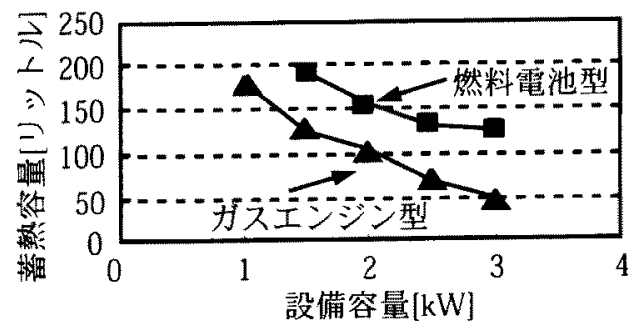

図 9 マイクロコジェネの設備容量に対する蓄熱 容量の推移 (給湯䓛荷として1時間の平均值を用 いた場合)

Fig. 9. Heat-storage capacity as a function of capacity of $\mu \mathrm{CGS}$ evaluated by using hourly averaged hot water load pattern.

がい、必要な蓄熱容量は前節の桱討の場合 (図 6)よりも小 さくなっている。設備容量が $3.0 \mathrm{~kW} の$ 場合、1 時間当たり で平均化された給湯負荷データを用いた場合に算定された 蓄熱容量は、分オーダーの給湯負荷データを用いた場合と 比較して、ガスエンジン型で $53 \%$ 、燃料電池型で $15 \%$ 小 さい。この理由について図 10に示す 1 時間当たりで平均化 された給湯負荷データもしくは分オーダーの給湯負荷デー 夕を用いた場合の給晹負荷とマイクロコジエネ供給熱量と の関保を表す概念図を用いて説明する。本システムではマ イクロコジェネからの回収熱のみで給湯負荷を賄っている。 このため、同図 (b) のように給湯負荷の累積值よりもマイ クロコジェネの供給熱量の累積値のほうが常に大きくなけ ればならない。また、本論文では省エネルギー性を目的と しているため、蓄熱槽での熱損失を小さくする必要がある。 このため、同図 (b) のように給湯負荷の累積值とマイクロ コジェネの供給熱量の累積値とができるだけ近くなるよう にマイクロコジェネの運転パターンが決定される。

図10からすかるように、1時間当たりで平均化された給 湯負荷データを用いた場合には、各々の給湯負荷の時間変 化が平均化されるため、マイクロコジェネからの供給熱量 の累積值と給湯負荷の累積值との差が小さい。一方、分才一 ダーの給湯負荷データを用いた場合には、個々の給湯負荷 の時間変化がマイクロコジェネの運転パターンの決定に直 接的に影響する。このため、図 10に示すように、マイクロ コジェネからの供給熱量の累積值と比較して、給湯負荷の 累積值の時間変化は大きくなる。この結果、1 時間当たりで 平均化された給湯負荷データを用いた場合のほうが分オー ダーの給湯負荷データを用いた場合よりも最大蓄熱量が小 さくなり、蓄熱容量も小さくなる。

なお、給湯負荷として 1 時間の平均值を使用した場合で も、一次エネルギー削減量は図 8に示した結果とほぼ同様 の結果となった。これは、本モデルの場合、補助熱源の導 入を想定していないため、1 日の給湯負荷の合計熱量でマ イクロコジェネの運転時間が決定されてしまうためである。 このように、マイクロコジェネの導入を検討する場合、多 


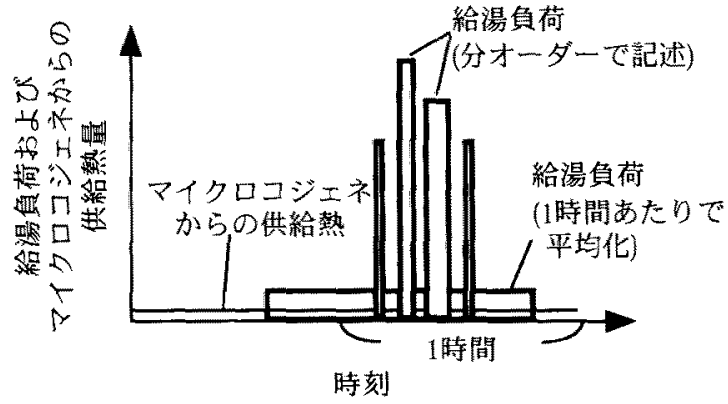

(a)給湯負荷の時間変化

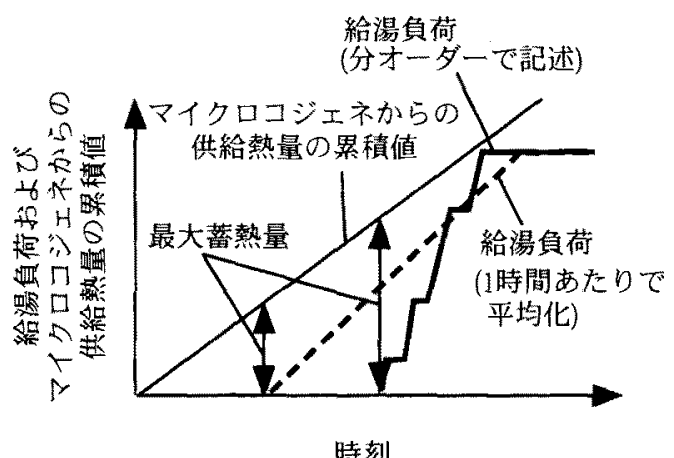

(b)給湯負荷の紫積値の時間変化

図 10 給湯負荷とマイクロコジエネ供給熱量との 相関

Fig. 10. Relationship between hot water load pattern and hot water supply by $\mu \mathrm{CGS}$.

数の負荷発生源を有する集合住宅の給湯負荷パターンを比 例換算し、負荷発生源が限定されている戸建住宅のモデル 化に用いた場合には、蓄熱容量を過小評伍することになる。

\section{〈3・3〉 マイクロコジェネ導入の経済性}

マイクロコジェネ導入の経済性を評価するため、マイク ロコジェネ導入に関する年間総コストを算定する。本論文 では、年間総コストを以下のように算定した。

年間総コスト $=$

$($ 年間の設備費 $)+($ 年間の電力・ガス料金 $)$

-(年間の売電額)

設備費は、マイクロコジェネの導入にともなって必要と なる設犕 (マイクロコジェネおよび蓄熱槽) の費用を一年 当たりに換算した值である。本研究では、資本回收倸数を 0.103 (回収年数 15 年、年利 $6 \%$ )として、一年当たりの設 備費を算定した。なお、蓄熱槽を除くマイクロコジェネの 設備単価は、現在の開発目標 $(50$ 万円 $/ \mathrm{kW})$ を考慮して、 20 万円 $/ \mathrm{kW} 600$ 万円 $/ \mathrm{kW}$ で変化させた。また、蓄熱槽の 価格は、現在の価格状況を考慮して1リットルあたり 600 円とした。

年間の電力・ガス料金は、平成 13 年 2 月現在の東京電力 の従量電灯 B 料金および東京ガスの住宅向け適用料金 (東

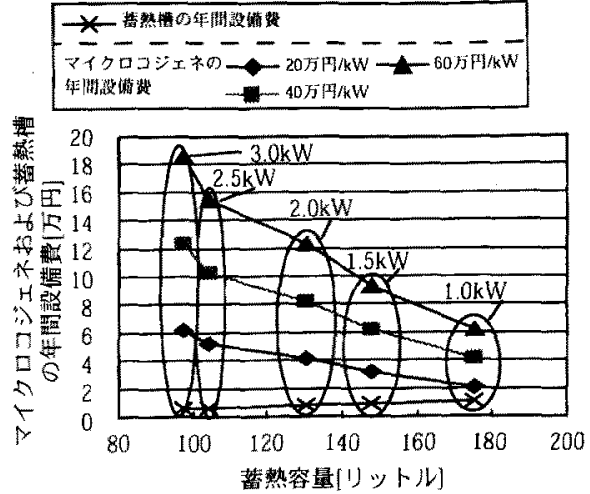

(a)ガスエンジン整

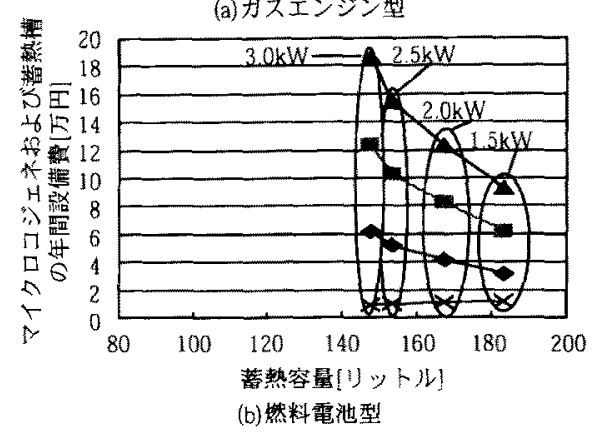

図 11 蓄熱容量に対する年間の設備費の推移 Fig. 11. Annual installation cost of $\mu \mathrm{CGS}$ as a function of heat-storage capacity.

京地区等)に基づいて算定した。また、売電による収入の 算定にあたっては、売電を行う時間帯に関わらす $\mathrm{kWh}$ 当 たりの売電価格を一定と想定し、年間の売電電力量に $\mathrm{kWh}$ 当たりの売電価格を乗じて、年間の売電額を算定した。

比較ケースでは、ガス給湯器 (1台あたり 30 万円) の設 備費、および各月の電力・ガス消費量を考慮して、総コス トを算定した。

蓄熱容量の規模の変化が年間の設備コストに及ほす影響 を評価した。その結果を図11に示す。マイクロコジェネの 設備コストと比較して、蓄熱槽の設備コストの変化は小さ い。さらに、蓄熱容量の大きさが小さくなるにつれて、マ イクロコジェネの設備容量が大きくなり、設備費コストに 占める蓄熱槽のコストの割合が小さくなる。したがって、 マイクロコジェネの設備費よりも蓄熱槽の設備費の方が安 価であるために、マイクロコジェネの設備容量が小さいほ ど蓄熱容量が大きくなるものの、年間設備費は小さくなり、 経済的に有利となる。ただし、蓄熱槽の規模が大きくなる ので、実際に導入する埸合には、設置スペースについても 考虑する必要がある。

年間の電力・ガス料金を図 12 に示す。系統への売電単価 は、現在の各電力会社の余剩電力の買い取り単価および一 般住宅における電力量料金を考慮して、5 円/ kWh もしく は 15 円/kWhの 2 通りとした。マイクロコジェネによる 電力供給のため、同図に示すように比較ケースよりも買電 


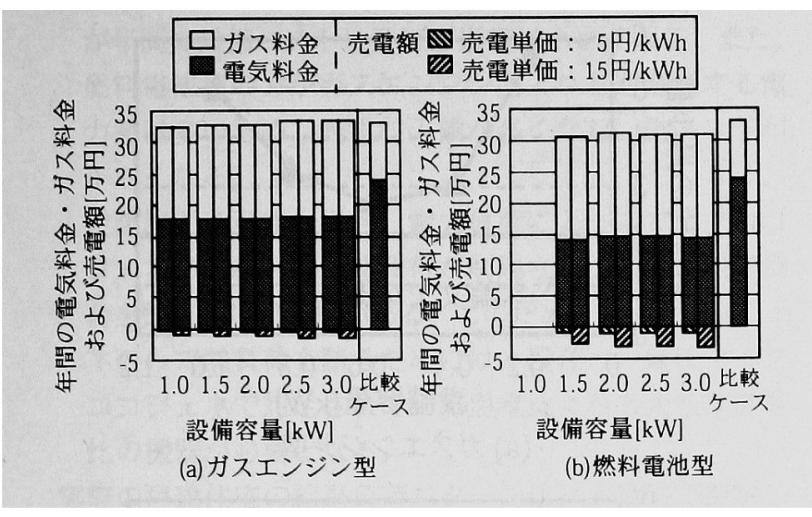

図 12 年間の電力料金・ガス料金および売電額

Fig. 12. Annual electric and gas charge and annual sales of electricity.

量は減少し、購入ガス量は增加する。ガスエンジン型より も燃料電池型の方が機器の総合効率が高いため、燃料電池 型の電カ・カス料金の削减額はガスエンジン型よりも大き くなる。また、ガスエンジン型、燃料電池型のいずれの場 合も、給湯負荷の規模でマイクロコジェネの運転時間が決 定されるため、設備容量に関わらずマイクロコジェネから の発電量は等しい。そのため、設備容量の変化に関わらず、 電力・ガス料金はほぼ等しくなる。さらに、然料電池型の 方がガスエンジン型よりも機器の熱電比が小さいため、設 備利用率が高く、逆潮流する電力量は多い。そのため、然 料電池型の方がガスエンジン型よりも売電収入顧が多くな る。また、売電単価が高いほど収入が多くなるため、売電 単価が 5 円/kWh の場合よりも 15 円/kWh の場合の方が 総コストは小さくなる。

設備費と電力料金・ガス料金および売電額とを含めた年 間の総コストを図 13に示す。図11および図 12に示したよ うに、設備費は設備容量の增加とともに大きくなるものの、 電力・ガス料金はほとんど変化しない。このため、設備容 量の增加とともに年間の総コストは大きくなる。また、ガ スエンジン型と比較して、燃料電池型の方が電力・ガス料 金の削隇額が大きく、売電収入も多い。したがって、ガス エンジン型と燃料電池型の双方の $\mathrm{kW}$ あたりの設備コスト が等しい場合には、総合効率の高い燃料電池の方が経済的 なメリットが大きいといえる。今後、マイクロコジェネの 設備コストが安価になり、かつ売電単価が一般住宅の電力 量料金と同水準であるならば、比較システムよりも年間総 コストが小さくなり、省エネルギー性に加え経済性も有利 なシステムとなる。

\section{4. 逆潮流が不可能な場合のマイクロコジェネ導入可 能性}

逆潮流が不可能な場合、電力負荷によってマイクロコジェ ネの出力が制限される。しかも、電力負荷がマイクロコジェ ネの最低出力より小さい場合には、マイクロコジェネを運

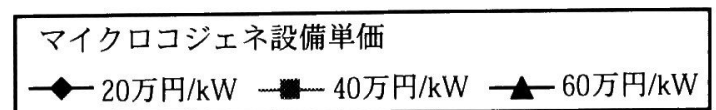

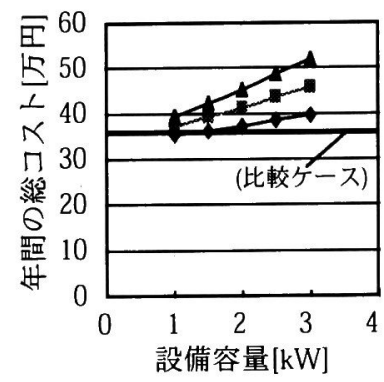

(i) 売電単価 : 5 円/kWh

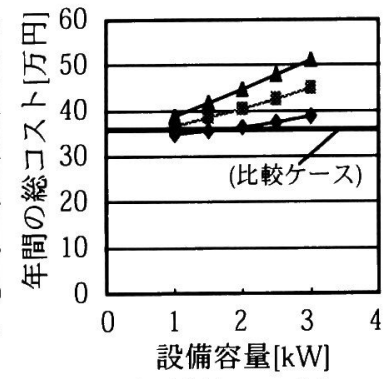

(ii)売電単価 : 15 円 $/ \mathrm{kWh}$ (a)ガスエンジン型

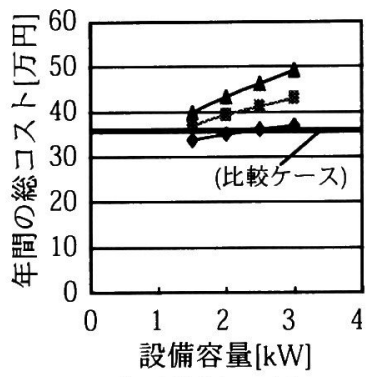

(i) 売電単価 : 5 円 $/ \mathrm{kWh}$

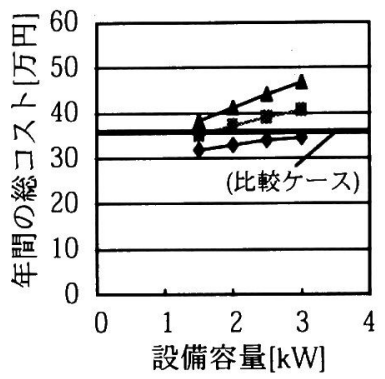

(ii) 売電単価 : 15 円/kWh (b)燃料電池型

図 13 年間の総コスト

Fig. 13. Annual cost in order to operate $\mu$ CGS in house.

転することができない。そのため、マイクロコジェネから の熱供給可能量は、マイクロコジェネの設備容量だけでな く、電力負荷の規模によっても変化する。特に、冷房・暖 房負荷が存在せず、電力負荷が小さくなる中間期において、 供給可能熱量が小さくなり、マイクロコジェネ単独では全 ての給湯負荷を賄えない可能性がある。

そこで、マイクロコジェネからの 1 日の最大供給可能熱 量を評価した。一例として、マイクロコジェネの設備容量を $0.5 \sim 3.0 \mathrm{~kW}$ で変化させた場合について、 5 月の 1 日の最大 供給可能熱量の推移を図 14に示す。なお、図の絴軸は、1 日の給湯負荷の合計値で規格化して表している。同図 (a)、 (b) のように、逆潮流が可能である場合、電力負荷によっ てマイクロコジェネの運転が制限されないため、マイクロ コジェネの熱供給可能熱量は、設備容量に比例して增加す る。同図 (b) に示すように、熱供給能力の小さい然料電池 型であっても、設備容量が $1.0 \mathrm{~kW}$ 以上であれば、マイク ロコジェネからの供給可能熱量は、1 日の給湯負荷の合計 值よりも大きくなる。一方、逆潮流が不可能な場合、電力 負荷によってマイクロコジェネの運転可能な時間帯が制限 されるため、マイクロコジェネからの 1 日の供給可能熱量 は、1 日の給湯負荷の合計値よりも小さくなる。この場合、 


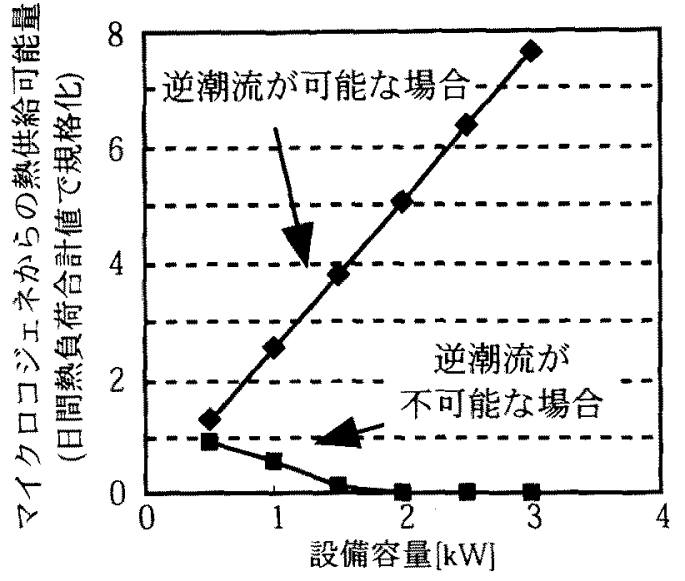

(a) ガスエンジン型

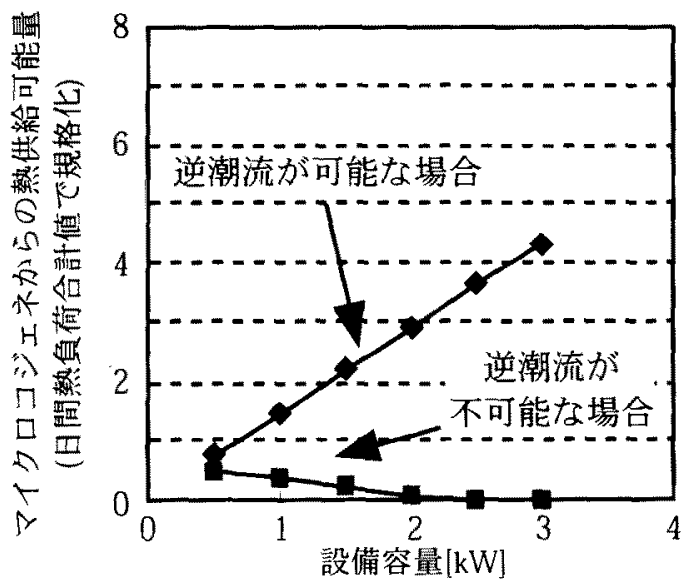

(b) 燃料電池型

図145月におけるマイクロコジェネからの最大 供給可能熱量

Fig. 14. Maximum value of heat supply from $\mu$ CGS in May.

マイクロコジェネ単独では給湯負荷を賄うことができない ため、ガス給湯器等の補助熱源が必要となり、マイクロコ ジエネを「給湯機器の代替」として位置づけられなくなる。

次に、ガスエンジン型、燃料電池型それぞれの場合につ いて、設備容量を $0.2 \mathrm{~kW}$ から $1.0 \mathrm{~kW}$ まで変化させ、逆潮 流が不可能な場合にマイクロコジェネのみで熱負葆を賄う ために必要な機器の熱電比の最小值を算出した。結果を図 15に示す。比較のため、本論文中で想定した熱電比も図中 に示した。逆潮流が不可能な場合、マイクロコジェネのみ で熱負荷を賄うためには、現在、一般にマイクロコジェネ で想定されている熱電比よりも大きな熱電比の機器が必要 となる。また、設備容量の変化と熱電比の最小値との相関 をみると、設備容量が $0.2 \mathrm{~kW}$ から $0.6 \mathrm{~kW}$ の範囲では、設 備容量が大きくなるにつれ、マイクロコジェネの時間当た りの熱回収量が大さくなるため、必要な熱電比が小さくな る。一方、設備容量が $0.6 \mathrm{~kW}$ より大きくなると、電力 に関する最低出力制約により、マイクロコジェネを運転で

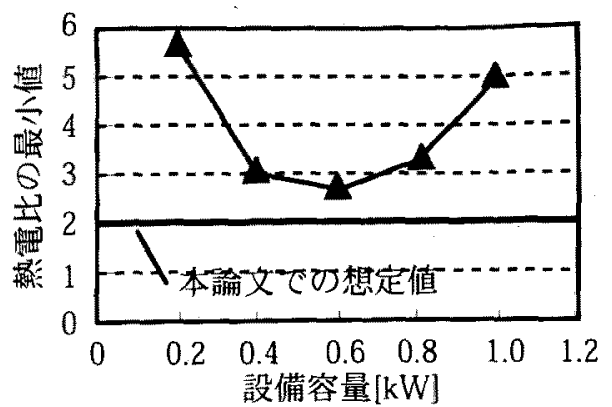

(a) ガスエンジン型

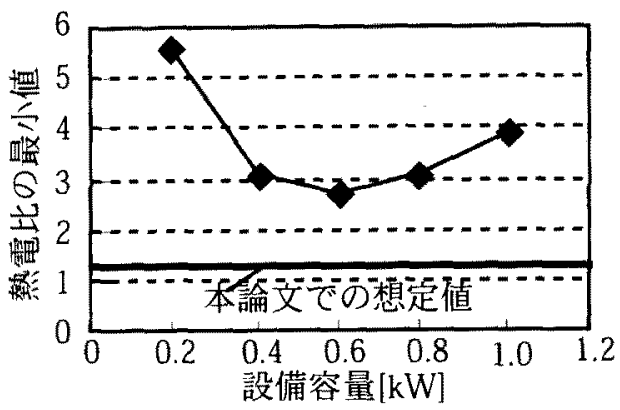

(b) 燃料電池型

困 15 マイクロコジェネの熱電比の最小值

Fig. 15. Minimum value of heat-to-electricity ratio of $\mu \mathrm{CGS}$.

きない時間帯が多くなるため、必要な熱電比が大きくなる。 なお、発電された電力でお湯を沸かし、給湯を行うことに より、等価的に図 15に示したような熱電比をもつシステム を奉現するこよが可能である。今後、このようなシステム についても評価を行う必要がある。

5. ఓとめ

本論文では、户建住宅を対象として、分笨位の給湯負荷 データを用いて、蓄熱容量および省エネルギ一性について 評洒した。本論文で得られた知見を以下にまとめる。

・逆潮流が可能な場合、マイクロコジェネの導入によっ て一次エネルギー消費量を削減できる。また、マイク ロコジェネの設備容暈が $3.0 \mathrm{~kW}$ の場合、蓄熱容量は、 ガスエンジン型の場合 97 リットル、燃料電池型の場合 148 リットルであり、実現可能な籍囲内で、臣建住宅 にマイクロコジェネを導入できることを確認した。

・給湯負荷データとして1時間值を用いた場合、給湯負 荷の急激な時間変化を考慮することができないため、 必要な蓄熱容量を過小評価する可能性がある。設備容 量が $3.0 \mathrm{~kW}$ の場合、1 時間当たりで平均化された給湯 負何データを用いた場合に算定された蓄熱容量は、分 オーダーの給湯負荷データを用いた場合と比較して、 ガスエンジン型で $53 \%$ 、燃料電池型で $15 \%$ 小さい。

・経済性の評価では、蓄熱容量の大きさが小さくなるに つれて、設備費コストに占める蓄熱槽のコストの割合 が小さくなり、蓄熱槽の設備容量によるコストの違い 
が年間の設備コストに及ぼす影響は小さくなる。また、 然料電池型の方がガスエンジン型よりも逆潮流する電 力量は多いため、売電収入額が多くなり、総コストが 小さくなる。

・逆潮流が不可能な場合、電力負荷によってマイクロコ ジェネの運転可能な時間帯が制限され、必要な給湯負 荷を賄えない可能性がある。このため、マイクロコジェ ネのみで熱負荷を賄うためには、現在、一般にマイク ロコジェネで想定されている熱電比よりも大きな熱電 比の機器が必要となる。

実際の戸建住宅の給湯負荷パターンは、本論文で想定し たように、必ずしも時間的にも量的にも確定的ではなく、発 生時刻や使用量は毎日変動すると考元られる。そこで、今 後は、負荷の時間的、量的な変動を考慮した場合のシステ ムの設備規模や最適運用形態を検討する方針である。また、 マイクロコジェネと補助熱源を組み合わせて導入した場合 の導入形態や設備規模や、逆潮流が可能なマイクロコジェ ネが大規模に導入された場合にエネルギーシステム全体に 及ぼす影響についても評価する方針である。

(平成 12 年 9 月 27 日受付, 平成 13 年 4 月 2 日再受付)

\section{文献}

（1）「平成 9 年度家庭設圆型小規模分散型エネルギーシステムに関する 調查報告書」、(財) 産業創造研究所、(1998)

（2）「平成 10 年度新工ネルギ-等導入促進調查 民生用小型分散型工 ネルギーシステムに関する研究成果報告書」（社）日本電機工業会、 (1999)

（3）(財) 日本エネルギー経済研究所エネルギー計量分析センター, $\lceil\mathrm{EMDC} /$ エネルギー・経済統計要筧（2000 年版）」，(財) 省工 ネルギーセンター, p.73 (2000)

（4）中部電力株式会社電気利用技術研究所，「近未来住宅に関する調查 研究」, p.60 (1993)

（5）「平成元年度 省エネルギー形カス不然焼機器の然焼性能の標準化 に関する研究調查報告書」、(財) 日本カス機器検查協会、pp.8-11 (1991)

（6）尾島俊雄研究室,「建築の光熱水原単位 [東京版]」，早稲田大学出版 部, pp.153-158 (1995)

若圆芳 品 (学生員) 1973 年 11 月 9 日生。98 年 3 月名古

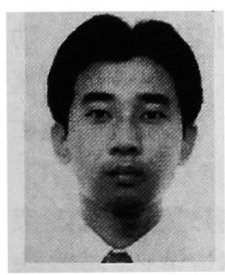

加 霹 丈 佳

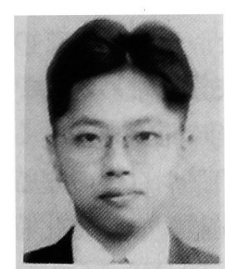

（正員） 1968 年 5 月 7 日生。 96 年 3 月名古屋大学 大学院工学研究科博士課程後期課程修了。同年 4 月名古屋大学理工科学総合研究センター助手、現 在に至る。工学博士。超電導電力システム、エネ ルギーシステムに関する研究に従事。エネルギー・ 資源学会会員。

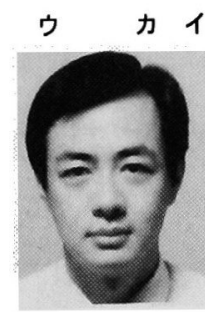

横 水 康 伸

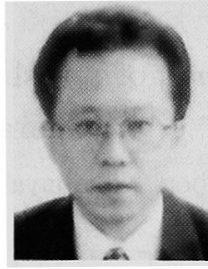

岡本達

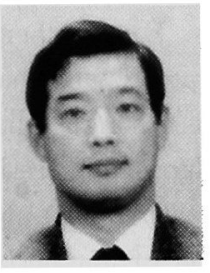

鈴 置 保 雄

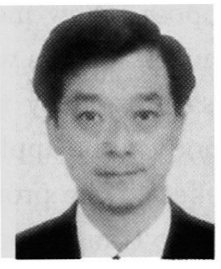

（正員） 1950 年 5 月 26 日生。 78 年 3 月名古屋 大学大学院工学研究科博士課程後期課程修了。同 年 4 月名古屋大学工学部助手、 87 年同講師、 89 年同助教授、 95 年 4 月名古屋大学理工科学総合 研究センター教授、現在に至る。工学博士。主と して、電気電子材料、エネルギーシステムに関す る研究に従事。IEEE、応用物理学会、高分子学 会、エネルギー・資源学会会員。 